\title{
Oilseed rape allergy: is it significant? An investigation into its prevalence in an East Anglian population, UK
}

\author{
A Trinidade*, S Kumar, A Farboud, M Shakeel, P Leong \\ From Canadian Society of Allergy and Clinical Immunology Annual Scientific Meeting 2009 \\ Halifax, Canada. 22-25 October 2009
}

\section{Background}

Oilseed rape production is widespread in East Anglia. Many patients attending our rhinology clinic for seasonal allergy claim that they are allergic to it.

\section{Aim}

To determine the prevalence of oil-seed rape allergy in our population.

\section{Population}

General population attending a rhinology and allergy clinic in an East Anglian district general hospital, UK.

\section{Methods and materials}

Retrospective chart analysis. The results of 1475 consecutive patients who underwent skin prick allergy testing over a 2-year period were analysed.

\section{Results}

Allergy to grass pollen was found to be most common $(\mathrm{n}=375,25.1 \%)$ followed by house dust mite $(\mathrm{n}=373$, $25 \%)$ and cereals $(n=301,20.1 \%)$. Oilseed rape allergy was relatively uncommon, comprising only $1.89 \%$ of the population tested $(\mathrm{n}=28)$.

\section{Discussion}

Despite the abundance of oil-seed rape in our geographical region, it does not seem to be responsible for most of our cases of seasonal allergy. Other environmental factors may be contributory.

Published: 12 May 2010

Edith Cavell Hospital, Peterborough, UK

\section{doi:10.1186/1710-1492-6-S1-P2}

Cite this article as: Trinidade et al:: Oilseed rape allergy: is it significant? An investigation into its prevalence in an East Anglian population, UK Allergy, Asthma \& Clinical Immunology 2010 6(Suppl 1):P2.
Submit your next manuscript to BioMed Central and take full advantage of:

- Convenient online submission

- Thorough peer review

- No space constraints or color figure charges

- Immediate publication on acceptance

- Inclusion in PubMed, CAS, Scopus and Google Scholar

- Research which is freely available for redistribution 